Sri Lanka J. Aquat. Sci. 17 (2012): 47-57

\title{
Economic viability of Asian sea bass (Lates calcarifer) and Tilapia (Oreochromis niloticus) small scale aquaculture systems in Sri Lanka
}

\author{
M. GAMMANPILA ${ }^{1 *}$ and M.S. SINGAPPULI ${ }^{2}$
}

${ }^{1}$ National Aquatic Resources, Research and Development Agency, Regional Research Centre, Kadolkele, Negombo, Sri Lanka

${ }^{2}$ Sevalanka Foundation, P.O. Box No. 03, $2^{\text {nd }}$ floor, No. 432 A, Colombo road, Boralesgamuwa, Sri Lanka

*Correspondence (gMeneke@ yahoo.com)

\begin{abstract}
Information on the economic viability of aquaculture is crucial for investors when assessing the feasibility of an aquaculture project. As such information has been scarce in Sri Lanka, present study evaluates the production cost and profitability of two small scale aquaculture practices in Sri Lanka. These are 1) Asian sea bass (Lates calcarifer) cultured in net cages at Nadathivu canal in Kinniya in 2009 2) Monoculture of Genetically Improved Farmed Tilapia (GIFT) produced under intensively in net cages in Maduganga estuary in 2009. In this study, data on yield, costs and returns of farming were collected to quantify production costs and to assess the profitability.

Economic analysis of the production systems revealed that the cost of tilapia and sea bass production per kg were Rs. 142.19 and 268.62 respectively. The yield of tilapia/ $\mathrm{m}^{3}$ was measured to be $22.5 \mathrm{~kg}$ and the yield of sea bass $/ \mathrm{m}^{3}$ was 22.1 $\mathrm{kg}$. Tilapia cage culture had the highest return on investment $(40.65 \%)$ and required $353.1 \mathrm{~kg}$ of the total production to reach the break-even point compared to sea bass.

Feed was the main cost factor which was $66.21 \%$ for sea bass production while that of tilapia production was $60 \%$. The ratio of the variable cost in total costs of tilapia production was $74 \%$ while that of sea bass production was $82 \%$. The benefit cost ratio in tilapia production (1.40) was higher comparing to sea bass production (1.12). Culture of tilapia showed the highest viability and profitability of the two evaluated culture practices.
\end{abstract}

Key words: Cage aquaculture, Cost-benefit analysis, Economic viability, Sea bass, Tilapia. 


\section{Introduction}

Aquaculture production has increased steadily in recent years; it is the fastest growing food production sector and has become a valuable component of national development and poverty reduction plans in many areas (FAO 2006). To meet future demands for food fish supplies in rural areas in Sri Lanka, resources have been put in place to promote aquaculture development through various extensive, semi intensive and intensive aquaculture systems in marine, brackish and inland waters over the past few decades (http://www.fisheries.gov.lk).

Farming of fish and shrimps are income generating activities that are now being practiced in Sri Lanka. Some of them are still effective economic activities in many coastal areas with a significant socio-economic impact. Because of poor regard of aquaculture as an economic activity, it was difficult to promote its commercialization, as investors were not convinced that aquaculture could be a profitable enterprise (Gitanga et al. 2004). Economic considerations in selection of an appropriate aquaculture production system include its potential for economic returns, its economic efficiency and farmer's access to operating capital (Green et al. 1995). For most farming businesses, efficiency is measured in economic terms; that is, the amount of money spent on a farming activity (including costs of inputs, labor, management, opportunity cost for land and capital, etc.) is compared to the amount earned through the sale of produce (Brummett 2007). The level of production, farm prices and production cost are affected by net income of the farm (Bozoglu and Ceyhan 2009). Increase in farm productivity, reduction in production costs and increase in average farm revenue are major measures to increase net return.

Sustainable and profitable operations can be achieved only through better understanding of the relevant elements and of their relationships in the entire production process (Brugee et al. 2007). Therefore, it is essential to develop and manage of a farm to know the production costs and its evolution and to determine where cost reduction can be achieved.

Several studies have focused of economic evaluation of aquacultural production systems existing in Egypt (Soliman and Gabor 1988; Ei Hendy 1990; Essa et al. 2005), Nigeria (Olagunju et al. 2007), Korea (Lipton and Kim 2007), and in the Philippines (Hurtado et al. 2001). The results of Essa et al. (2005) demonstrated that semi-intensive and intensive culture of sea bass cage culture possessed the best survival rate and production $\left(86.3 \%\right.$ and $5.4 \mathrm{~kg} / \mathrm{m}^{3}$ vs $74.2 \%$ and $4.78 \mathrm{~kg} \mathrm{~m}^{-3}$ respectively) and intensive red tilapia culture had significantly $(\mathrm{P}<0.05)$ higher production $\left(10.24 \mathrm{~kg} \mathrm{~m}^{-3}\right)$ than those of semi-intensive culture $\left(6.43 \mathrm{~kg} \mathrm{~m}^{-3}\right)$. A comparative analysis of the technical and economic parameters of two community led aquaculture approaches: the semi-closed water bodies and the floodplain water bodies based systems in Bangladesh were evaluated by Mustafa and Brooks (2009). Analysis of economic profitability of Nile tilapia (Oreochromis niloticus) production in Kenya (Aloyce et al. 2007) indicated that mixed-sex culture was inferior to mono-sex culture and polyculture with cat fish due to polyculture does not add a significant amount of operation costs. Production cost data help the farmers in decision making and in adjusting to changes and determine the price 
level under which the product cannot be sold without losses. Thus, a careful investigation of the economics of fish farming would benefit both producers and policymakers in designing appropriate policy measures enabling increase of profitability in aquaculture (Ahmed et al. 2008). According to Mwangi (2007), the investors will not only need to practice responsible aquaculture but also need to make a profit to maintain sustainable aquaculture. For this reason, relevant authorities need to have appropriate information such as aquaculture production by different species and culture systems, input cost and sources availability, marketing demand and supply, prices offered to investors in their process of making economic decisions on aquaculture investments.

Despite lack of appropriate information, various organizations have continued to promote aquaculture development through various aquaculture projects over the last few decades. However, the projects focused more on the biological aspects rather than paying critical attention to the financial aspects of the production. Efficient financial management of aquaculture can make the difference between profits and losses (Carole and Ivano 2005). Hence lack of information on financial aspects would negatively impact on aquaculture development of Sri Lanka. Therefore, the purpose of the study was to assess production cost and profitability (economic viability) of semi intensive monoculture of Asian sea bass (Lates calcarifer) and GIFT Tilapia (Oreochromis niloticus) produced in net cages in Sri Lanka.

\section{Materials and Methods}

The pilot scale cage farming of sea bass and GIFT tilapia have been established since 2009 in Nadathivu canal in Kinniya, Trincomalee District and in Ampe village at Maduganga, a RAMSAR site, respectively. Each study site was consisted of 10 cage units ( $3 \mathrm{~m} \times 3 \mathrm{~m} \times 2 \mathrm{~m})$; five with mesh size of $1 \mathrm{~cm}$ (for fingerling rearing) and five with mesh size of $2.5 \mathrm{~cm}$ (for grow out phase). Each unit was suspended from a floating raft anchored to the estuary bed. The frame of raft was made of coconut and timber which allowed for floating with plastic drums (Figures 1 and 2). Net cages had a depth of $2 \mathrm{~m}$ with $1.5 \mathrm{~m}$ immersed in the water. The total volume of each cage was nearly $13.5 \mathrm{~m}^{3}$. Fingerlings of sea bass (Lates calcarifer) and GIFT tilapia of about $25 \mathrm{~g}$ and $40 \mathrm{~g}$ respectively were stocked in $1 \mathrm{~cm}$ mesh cages at a density of 30 fish $\mathrm{m}^{-3}$ and 37 fish $\mathrm{m}^{-3}$.

During growing period (5.5 months) tilapia were hand fed on artificial farm made feed (protein $36 \%$, lipids $8.0 \%$, ash $10 \%$, moisture $8 \%$ ) at a rate of $6 \%$ of their live body weight, two times daily $(9.00$ am and $15.00 \mathrm{pm})$ during the first six weeks and thereafter at a rate of $4 \%$ of body weight per day. Moisture content of farm made feed was determined by oven drying method (AOAC 1980), crude protein content was determined by using Kjeltec machine and protein conversion factor (6.25) was used in converting nitrogen to crude protein. Crude lipid was determined by using the Soxhlet system to extracting lipids of samples by petroleum ether. Ash content was determined ignition of samples in a muffle furnace at $550^{\circ} \mathrm{C}$ for 16 hours. Ingredients that were used for feed formulations (\%) and chemical composition of fish diets are presented in figures 3 and 4. 

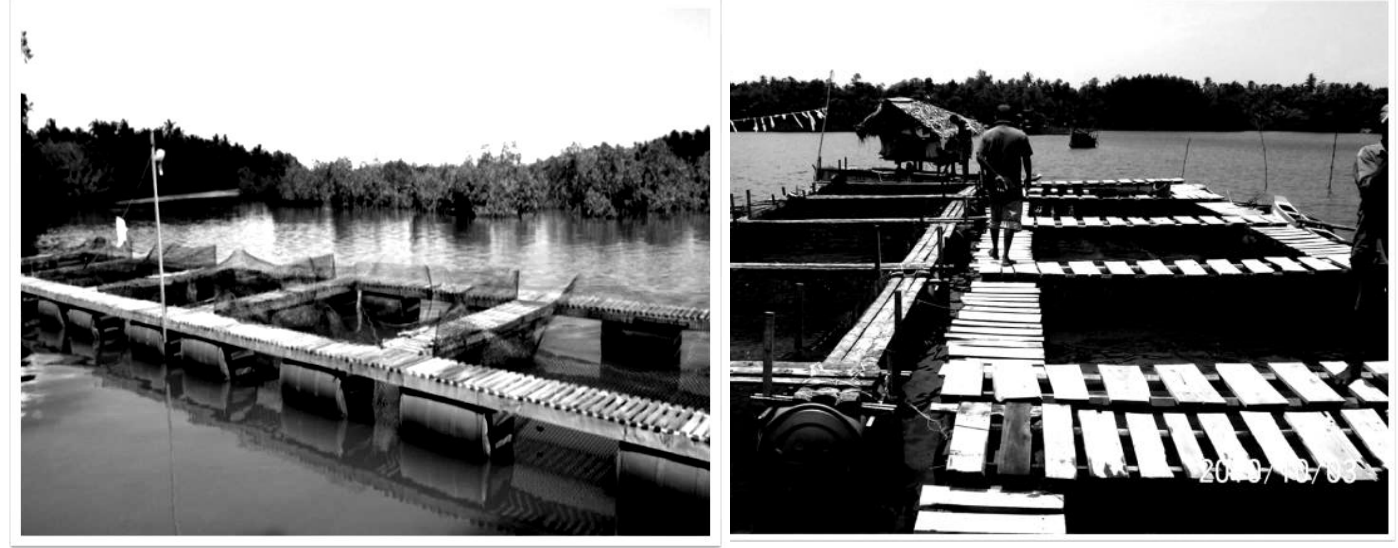

Figure 1. General view of pilot cages of Figure 2. General view of pilot cages of sea bass farm in Nadathivu canal in GIFT tilapia farm in Maduganga. Trincomalee.

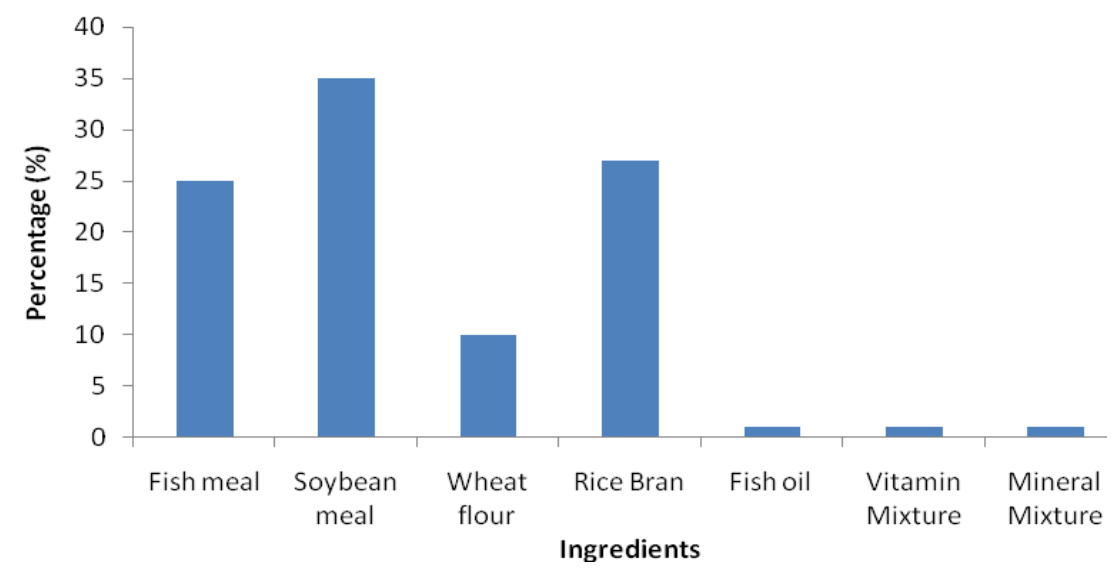

Figure 3. Diets composition of farm made feeds for red tilapia reared in pilot cages in Maduganga.

Sea bass were fed commercial pellet feed (protein 39\%, fat $7.0 \%$, fibre $4 \%$, and ash $11.7 \%$ ) at a rate of $6 \%$ of their body weight during first two month period. After two months, fish were transferred to large mesh cages and gradually introduced trash fish/fish waste and feeding rate was reduced up to $4 \%$ of their body weight. Fish were fed twice a day. A monthly sample of about 25 fish was collected from each cage and weighed, and the feed amount was readjusted accordingly.

Water samples were collected monthly from cages area for basic water quality parameters such as water temperature $\left({ }^{\circ} \mathrm{C}\right)$, salinity $(\mathrm{ppt})$, surface dissolved oxygen (DO) $\left(\mathrm{mg} \mathrm{l}^{-1}\right)$, surface water turbidity and $\mathrm{pH}$ according to the standard methods. The water temperature was measured in-situ to the nearest $0.1^{\circ} \mathrm{C}$ accuracy 
using a mercury thermometer, water salinity was measured using a salinity refractometer, whereas $\mathrm{pH}$ was determined with a portable $\mathrm{pH}$ meter $(\mathrm{HACH}$ Sension 1), Dissolved oxygen and turbidity were measured by using portable DO and turbidity meters (Table 1).

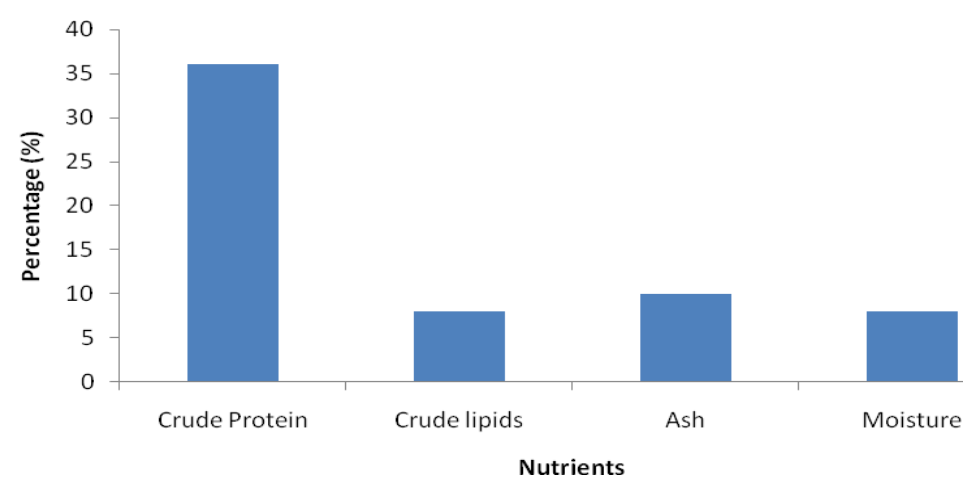

Figure 4. Proximate composition (\%) of farm made feeds for red tilapia reared in pilot cages in Maduganga.

At the end of culture period, growth performance and production were calculated as mentioned in Tables 2 and 3 .

Table 1 . Mean $( \pm$ SE) values of water quality parameters during culture period of sea bass and tilapia in net cages in Nadathivu canal in Trincomalee and Maduganga.

\begin{tabular}{lcc}
\hline Parameter & Sea bass & Tilapia \\
\hline Water Temperature $\left({ }^{\circ} \mathrm{C}\right)$ & $29.80 \pm 2.75$ & $29.20 \pm 1.97$ \\
Water Depth $(\mathrm{cm})$ & $325 \pm 35$ & $250 \pm 20$ \\
Salinity $(\% o)$ & $11.62 \pm 10.58$ & $9.80 \pm 3.51$ \\
$\mathrm{pH}$ & $7.55 \pm 0.85$ & $7.44 \pm 0.65$ \\
Dissolved Oxygen $\left(\mathrm{mg} \mathrm{l}^{-1}\right)$ & $5.70 \pm 1.55$ & $5.10 \pm 2.15$ \\
Turbidity (NTU) & $6.71 \pm 1.35$ & $4.68 \pm 2.05$ \\
\hline
\end{tabular}

Table 2. Growth performance of sea bass and GIFT tilapia reared in net cages in Nadathivu canal in Trincomalee and Maduganga.

\begin{tabular}{lll}
\hline Parameter & Sea bass & GIFT tilapia \\
\hline Culture period (days) & 158 & 158 \\
No. of fish/m ${ }^{3}$ & 30 & 37 \\
Total volume of cage $\left(\mathrm{m}^{3}\right)$ & 13.5 & 13.5 \\
Mean initial fish weight $(\mathrm{g})$ & 25 & 40 \\
Mean final fish weight $(\mathrm{g})$ & 716 & 640 \\
Survival rate $(\%)$ & 83.4 & 95 \\
Daily weight gain (g/day) & 4.37 & 3.79 \\
\hline
\end{tabular}


The methods for economic analysis used in this study were as follows. The economic analysis, data on yield, cost and return of farming were used to calculate production cost and profitability. Total production costs for both sea bass and tilapia include fixed and variable costs. Variable cost is directly related to the scale of farm operations at a given time period. Variable costs in production are cost of feed, juvenile, transport and cost for labour. Fixed cost includes depreciation of cages and its opportunity cost. The opportunity cost was estimated at the interest rate of $4 \%$ per annum and annual depreciation value of the cages was calculated by value of the cages divided by their expected life time. The economic viability was analyzed using profitability indicators such as rate of return on total cost, net profit, payback period and benefit-cost ratio. The total revenue (TR) was calculated by multiplying the total amount of production $(\mathrm{Q})(\mathrm{kg})$ by its average market price $(\mathrm{P}) . \mathrm{TR}=\mathrm{Q} * \mathrm{P}$. Net profit (NP) was calculated as the difference between total revenue from fish sale (TR) and total cost of production (TC). NP=TR-TC. Benefit-cost ratios defined as total revenue from fish sale divided by total production cost. Break-even point (BEP) is the level of production at which the total cost and total revenue are equal (Curtis and Howard 1993). Break-even point (BEP) calculated as following equation.

$$
\mathrm{BEP}=\mathrm{TFC} / \mathrm{SUP}-\mathrm{VCUP})
$$

where, TFC $=$ Total Fixed Cost; VCUP $=$ Variable Cost per Unit Production and $\mathrm{SUP}=$ Selling Price per Unit Production

Payback period is the length of time required to cover the cost of an investment and can be calculated by dividing the investment cost by the net annual income. This gave the time in years that the enterprise would take to pay back the initial investment cost.

\section{Results}

Economic analysis of the production systems revealed the cost of tilapia and sea bass production per $\mathrm{kg}$ were Rs. 142.19 and Rs. 268.62 respectively. The yield of tilapia was measured to be $22.5 \mathrm{~kg} \mathrm{~m}^{-3}$ and the yield of sea bass was $22.1 \mathrm{~kg} \mathrm{~m}^{-3}$. Net income of product was found to be Rs. $57.8 \mathrm{~kg}^{-1}$ and Rs. $31.4 \mathrm{~kg}^{-1}$ for tilapia and sea bass systems respectively. Tilapia cage culture had the highest return on investment $(40.7 \%)$ and required $353.1 \mathrm{~kg}$ of the total production to reach the breakeven point compared to sea bass.

Feed was the main cost factor and was $66.2 \%$ for sea bass production while that of tilapia production was $60 \%$. The ratio of the variable cost in total costs of tilapia production was $74 \%$ while that sea bass production was $82 \%$. The benefit cost ratio in tilapia production (1.40) was higher compared to sea bass production (1.12). 
Table 3. Comparative economic analysis for the production of tilapia and seabass.

\begin{tabular}{|c|c|c|c|c|}
\hline \multirow[b]{2}{*}{ Cost factors } & \multicolumn{2}{|c|}{ Tilapia production } & \multicolumn{2}{|c|}{ Sea bass production } \\
\hline & Cash (Rs.) & $\begin{array}{l}\text { Non -cash } \\
(\mathrm{Rs})\end{array}$ & Cash (Rs.) & $\begin{array}{c}\text { Non - } \\
\text { cash (Rs) }\end{array}$ \\
\hline Initial cost & $317,550.00$ & & $331,500.00$ & \\
\hline $\begin{array}{l}\text { Cage construction ( } 5 \text { fingerling } \\
\text { cages \& } 5 \text { grow out cages) } \\
(3 \mathrm{~m} \times 3 \mathrm{~m} \times 2 \mathrm{~m})\end{array}$ & $306,750.00$ & & $320,000.00$ & \\
\hline Transport cost & 10,800 & & $11,500.00$ & \\
\hline Production (Total cost) & $159,180.00$ & $56,952.20$ & $330,550.00$ & $70,502.00$ \\
\hline Fixed cost & & $26,585.00$ & & $33,280.00$ \\
\hline Cage depreciation (per year) & & $25,562.50$ & & $32,000.00$ \\
\hline Opportunity cost ( $4 \%$ per year) & & 1022.50 & & 1280.00 \\
\hline Variable cost/per cycle & $159,180.00$ & $30,367.20$ & $330,550.00$ & $37,222.00$ \\
\hline $\begin{array}{l}\text { Fingerling cost Tilapia (Rs. } 5 \times \\
2500 \text { ) }\end{array}$ & $12,500.00$ & & $50,000.00$ & \\
\hline $\begin{array}{l}\text { Fingerling cost sea bass (Rs. } \\
20 \times 2500)\end{array}$ & & & & \\
\hline $\begin{array}{l}\text { Family labour (320 labour hrs } \\
\times \text { Rs. } 75 \text { ) }\end{array}$ & & $24,000.00$ & & $24,000.00$ \\
\hline $\begin{array}{l}\text { Feed cost tilapia (farm made } \\
\text { feed for first } 2 \text { months/Rs } 90 \\
\text { per } \mathrm{kg} \text { ) }\end{array}$ & $35,640.00$ & & $91,800.00$ & \\
\hline $\begin{array}{l}\text { Feed cost seabass (commercial } \\
\text { feed for first two months) }\end{array}$ & & & & \\
\hline $\begin{array}{l}\text { Feed cost (farm made feed for } \\
\text { last four months/Rs. } 90 \text { per kg) }\end{array}$ & $95,040.00$ & & $173,750.00$ & \\
\hline $\begin{array}{l}\text { Feed cost (trash fish for last } \\
\text { four months Rs. } 24 \times 6950 \mathrm{~kg} \text { ) }\end{array}$ & & & & \\
\hline Transport & $16,000.00$ & & $15,000.00$ & \\
\hline Opportunity cost (4\% per year) & & 6367.20 & & 13222.00 \\
\hline Number of crops per year & 02 & & 02 & \\
\hline $\begin{array}{l}\text { Total production } \mathrm{kg} / \mathrm{crop} \\
\text { (tilapia - survival } 95 \% \text { and } \\
\text { mean final weight } 640 \mathrm{~g} \text { ) } \\
\text { (sea bass - survival } 83.4 \% \text { and } \\
\text { mean final weight } 716 \mathrm{~g} \text { ) }\end{array}$ & 1520 & & 1493 & \\
\hline Selling price $\mathrm{Rs} . \mathrm{kg}^{-1}$ & 200.00 & & 300.00 & \\
\hline Total revenue Rs. Crop ${ }^{-1}$ & $304,000.00$ & & $447,900.00$ & \\
\hline Net revenue Rs. Crop ${ }^{-1}$ & $144,820.00$ & & $117,350.00$ & \\
\hline Net profit Rs. Crop ${ }^{-1}$ & $87,867.80$ & & $46,848.00$ & \\
\hline $\begin{array}{l}\text { Rate of return on Total cost (\% } \\
\text { per crop) }\end{array}$ & 40.65 & & 11.68 & \\
\hline
\end{tabular}


Table 3. Continued.

\begin{tabular}{lcc}
\hline Production cost $\mathrm{kg}^{-1}$ (Total & & \\
production cost/production) & 142.19 & 268.62 \\
Net income $\mathrm{kg}^{-1}$ & 57.81 & 31.38 \\
Yield $\mathrm{m}^{-3}(\mathrm{~kg})$ & 22.5 & 22.12 \\
Benefit-cost ratio & $1: 4$ & $1: 1.12$ \\
Payback period - years & 1.81 & 3.54 \\
Break-even point $(\mathrm{kg})$ per crop & 353.06 & 620.09 \\
\hline
\end{tabular}

\section{Discussion}

Based on the economic indicators of the present study, it was clearly shown that tilapia culture was more profitable than sea bass farming. Sea bass farm conducted their operations much more capital investment comparing to tilapia farms. With these assets tilapia farm gained Rs. $57.8 \mathrm{~kg}^{-1}$ of net income while that of sea bass farm was Rs. $31.4 \mathrm{~kg}^{-1}$. Nevertheless in terms of production for unit volume, it was clear that both farms gave similar production. Tilapia culture had the highest values for net profit and rate of return on total cost indicating the highest viability in this evaluation. Further benefit-cost ratio in tilapia production was higher comparing to sea bass production. Essa et al. (2005) have shown that sea bass cultured in semi intensive systems ( $35.8 \mathrm{fish} \mathrm{m}^{-3}$ ) for 323 days and 50 fish m $\mathrm{m}^{-3}$ of tilapia for 159 days showed relatively lower production rates $\left(5.4 \mathrm{~kg} \mathrm{~m}^{-3}\right.$ and $\left.6.43 \mathrm{~kg} \mathrm{~m}^{-3}\right)$ compared to the present study. These results are encouraging because the payback period from this successful system was 1.61 years (semi-intensive culture of GIFT tilapia) more or less similar (1.81) to present study. Further intensive sea bass culture gives low economical profitability. Credit use pattern of sea bass farm also differed from tilapia farm. The sea bass farm used more credit for fingerlings and feed than the tilapia farm. The share of the variable cost in total cost of sea bass production was $82 \%$ while that of tilapia production was $74 \%$. Similarly due to higher production cost in sea bass farming, its profitability is lower than tilapia production. For sea bass production, feed had the highest cost $(66.2 \%)$ in total cost followed by $12.5 \%$ of fingerling cost. Similarly, feed was the main cost factor $(60.4 \%)$ in tilapia production and cost for fingerling followed it with share of 5.8\% of total cost. Therefore this study shows that decrease in feed and fingerling costs, increase feed efficiency are the major means of increasing profit for the sea bass farming.

In Sri Lanka several projects put in place to promote aquaculture during last decades. Many investments, except shrimp farming were promoted only as a family subsistence activity for supplementing protein source in rural areas. However, fish farmers do not have sufficient incentives to commercialise their activities. Due to various reasons, fish culture as an economic enterprise in Sri Lanka has remained in its infancy. Most important constraints were identified as high production cost, availability of fingerlings and high cost of commercial feed. Possible alternatives are trash fish and fish waste for sea bass culture but seasonality and availability remain as major concerns. Further, improving feed formulation and feeding practices will reduce feed costs. Development of a feed based on low cost, locally available ingredients would help improve farmers' profitability. Reductions in 
production costs and negative environmental impacts through bio-technological improvement and efficient management are important for sustainable development of aquaculture. Diversification of market, development of current market, supply of value-added products (fillets, precooked, etc), increased size range, improvement of product quality image may increase sustainability of sea bass and tilapia farming. Further success of aquaculture in Sri Lanka will not only depend on the use of higher yielding species and efficient aquaculture production technologies, but also on the confidence of investors.

\section{Acknowledgements}

The authors are thankful to Sewalanka Foundation for implementing the project and International Union for Conservation of Nature/Mangrove for the Future Program (IUCN-MFF) and Icelandic International Development Agency (ICEIDA) for financial assistance.

\section{References}

Ahmed, N., F. Ahammed \& M.V. Brakel 2008.

An economic analysis of fresh water prawn, Macrobrachium rosenbergii farming in Mymensingh, Bangladesh. Journal of the World Aquaculture Society 39(1): 37-50.

Aloyce, R. K., C.C. Ngugi, J. Mackambo \& K.K. Quagrainie 2007.

Economic Profitability of Nile tilapia (Oreochromis niloticus L.) production in Kenya. Aquaculture Research 38: 1129-1136.

AOAC 1980.

Official Methods of Analysis, 13th edition. Association of Official Analytical Chemists. Washington D.C.

Bozoglu, M. \& V. Ceyhan 2009. Cost and profitability analysis for Trout and Sea bass production in the Black sea, Turkey. Journal of Animal and Veterinary Advances 8 (2): 217-222.

Brugère, C., D. Soto, \& D.M. Bartley 2007.

Comparative environmental costs of aquaculture and other food production sectors: environmental and economic factors conditioning the global development of responsible aquaculture. In: Comparative Assessment of the Environmental Costs of Aquaculture and other Food Production Sectors: Methods for Meaningful Comparisons (D.M. Bartley, C. Brugère, D. Soto, P. Gerber \& B. Harvey eds). pp. 25-36. FAO/WFT Expert Workshop. 2428 April 2006, Vancouver, Canada. FAO Fisheries Proceedings. No. 10. FAO, Rome.

Brummett, R.E. 2007.

Comparative analysis of the environmental costs of fish farming and crop production in arid areas. In: Comparative Assessment of the Environmental Costs of Aquaculture and other Food Production Sectors: Methods for Meaningful Comparisons (D.M. Bartley, C. Brugère, D. Soto, P. Gerber \& B. Harvey eds). 221-228 pp. FAO/WFT Expert Workshop. 24-28 April 
2006, Vancouver, Canada. FAO Fisheries Proceedings. No. 10. FAO, Rome.

Carole, R.E. \& N. Ivano 2005.

Tilapia Farm Business Management and Economics. A Training Manual. Aquaculture/Fisheries Centre, Arkansas.

Curtis, M.J. \& A.C. Howard 1993.

Economics of Aquaculture. Food Product Press, New York.

EI Hendy, A.M. 1990.

Tilapia cage culture in Domyatt. Technical and economic evaluation. United scientists for projects and development symposium on biology and culture of tilapia, Egyptian fisheries co. for fishing and fish gears, 27-31 October 1990, Alexchdria, Egypt.

Essa, M.A., A.M. Helal, M.A.A. El-Wafa \& M.M. El- Gharabawy 2005.

Preliminary investigations in to the inshore marine cage culture in Egypt and their impact on marine resources. Egyptian Journal of Aquatic Research (32): 309-320.

FAO 2006.

State of world aquaculture. FAO Fisheries and Aquaculture Department, FAO, Rome.

Gitonga, N.K., H.M. Mbugua \& B. Nyandat 2004.

New approach to aquaculture extension in Kenya. Samaki News,

Department of Fisheries, Nairobi, Kenya 1(1).

Green, W.B., Z. El-Nagdy, H. Hebicha, I. Shake, D.A.R. Kenawy \& A.R. El-Gamal 1995.

Evaluation of Nile tilapia production systems in Egypt. Research report 9591, Pond Dynamics/ Aquaculture Collaborative Research Support Program. $02 \mathrm{p}$.

Hurtado, A.Q., R.F. Agbayani, R. Sanares \& M.T.R. de Castro-Mallare 2001. The seasonality and economic feasibility of cultivating Kappaphycus alvarezii in Panagatan Cays, Caluya, Antique. Aquaculture 199: 295-310.

Lipton, D. W. \& D. H. Kim 2007.

Assessing the economic viability of offshore aquaculture in Korea: An evaluation based on Rock Bream, Oplegnathus fasciatus, production. Journal of the World Aquaculture Society 38 (4): 506-515.

Mustafa, M.G. \& A.C. Brooks 2009.

A comparative study of two seasonal floodplain aquaculture systems in Bangladesh. Water Policy 11 (Supplement 1): 69-79.

Mwangi, M.H. 2007.

A comparative economic evaluation of farming of three important aquaculture species in Kenya. Final report, UNU Fisheries training programme, The United Nations University, Iceland. $65 \mathrm{p}$.

Olagunju, F.I., I.O. Adesiyan \& A.A. Ezekiel 2007.

Economic viability of cat fish production in Oyo State, Nigeria. Journal of Human Ecology 21(2): 121-124. 
M. Gmmanpila and M.S. Singappuli/Sri Lanka J. Aquat. Sci. 17 (2012): 47-57

Soliman, I. \& M. Gaber 1988.

An economic study of existing aquaculture systems in Egypt. Proceadings of the $13^{\text {th }}$ international congress for statistics, computer science, social \& Demographic research, 26-31 March 1988, Ain Shams University, Cairo, Egypt. 